\author{
Jurnal IImiah AL-Jauhari (JIAJ) \\ Volume 3 No 1, Juni 2018 \\ ISSN: $2541-3430$ \\ E-ISSN: 2541-3449 \\ Halaman 1 - 15
}

\title{
Pemikiran M. Amin Abdullah tentang Pendidikan Islam dalam Pendekatan Integrasi-Interkoneksi
}

\author{
Oleh : Abdullah Diu \\ (Kementerian Agama Kab. Bolaang Mongondow Utara)
}

\begin{abstract}
Abstrak
Dinamika pendidikan Islam di Indonesia menunjukan dikotomi, baik pendidikan Islam maupun pendidikan Umum. Pendidikan Islam sering dinobatkan hanya untuk kepentingan orang-orang yang tidak mampu atau miskin, memproduk orang yang eksklusif, fanatik, dan bahkan pada tingkat yang sangat menyedihkan yaitu terorisme pun dianggap berasal dari lembaga pendidikan Islam. Inilah yang disebut sebagai marginalisasi pendidikan Islam. Selain itu kualitas pendidikan Islam disebut sangat terbelakang atau kurang berkualitas. Pandangan M. Amin Abdullah tentang pendidikan Islam dalam pendekatan integrasi-interkoneksi mengurai basis pendekatan, yakni pendekatan historisfilosofis, normatif-teologis. Memiliki akar yang sangat jelas dalam dunia ilmu pengetahuan kedudukan pendidikan Islam mencakup hadlarah al-nash, hadlarah al-'ilm, dan hadlarah al-falsafah adalah upaya mempertemukan kembali antara ilmu-ilmu keislaman dengan ilmu-ilmu umum.
\end{abstract}

\footnotetext{
Abstract

The dynamics of Islamic education in Indonesia shows a dichotomy, both Islamic education and general education. Islamic education is often named only for the benefit of those who are poor or poor, produce exclusive, fanatical people, and even at a very sad level, terrorism is considered to be from Islamic education institutions. This is called the marginalization of Islamic education. Besides that the quality of Islamic education is called very underdeveloped or lacking in quality. M. Amin Abdullah's view of Islamic education in the integrationinterconnection approach breaks down the basis of the approach, namely the historical-philosophical, normative-theological approach. Having a very clear root in the world of science the position of Islamic education includes hadlarah alnash, hadlarah al-'ilm, and hadlarah al-falsafah is an effort to reconnect between Islamic sciences and general sciences.

Kata kunci:

Pemikiran M Amin Abdullah, Pendidikan Islam, Integrasi-Interkoneksi
} 


\section{Pendahuluan}

M. Amin Abdullah adalah salah satu nama pemikir Islam Indonesia yang cukup agresif melawan dikotomisasi pendidikan Islam di Indonesia. Seorang tokoh dari sekian banyak pemikir-pemikir tentang pendidikan Islam di Indonesia. Ia banyak berkiprah dalam bidang pendidikan, organisasi dan dakwah. Perjuangannya adalah ingin mengajak kaum muslimin Indonesia khususnya, untuk menghidupkan dan membangkitkan kembali (revitalisasi) ajaran Islam dari keterpurukan, sehingga umat Islam tidak ketinggalan dalam peradaban. Salah satu cara yang ditempuh oleh M. Amin Abdullah dalam membangkitkan keilmun dalam umat Islam dari keterpurukan adalah dengan mengajarkan pendidikan agama dan pendidikan umum lewat pendekatan integrasi-interkoneksi, dengan tidak ada pemisahan antara kedua model pendidikan tersebut.

Berangkat dari fakta bahwa dunia Islam dewasa ini cenderung membuat dikotomi antara ilmu agama dengan ilmu umum, maka M. Amin Abdullah, merasa perlu merekonstruksi fakta ini dan membuat sebuah restorasi paradigma keilmuan. Pemahaman dikotomi yang rigid ini membuat polarisasi yang dikotomis antara ilmu al-syarî'ah dan ilmu ghayr al-syarî'ah. Pemahaman ilmu ghayr al-syarî'ah yang jumlahnya jauh lebih banyak yang tidak penting untuk dipelajari, yang penting adalah ilmu al-syarî'ah, ilmu yang menuntun orang untuk memasuki surga dan menghindari neraka, merupakan hal yang bisa menghambat kemajuan kajian keislaman. ${ }^{1}$

Dikotomi ini sangat membekas di hati kaum Muslim. ${ }^{2}$ Terbukti sebagian besar orang sekarang masih terkesan bahwa ilmu keislaman adalah satu hal dan ilmu non-keislaman adalah hal lain. Dikotomi keilmuan seperti ini jelas akan merugikan dunia pendidikan Islam itu sendiri. Sebab ilmu-ilmu non-keagamaan dianggap tidak penting, sehingga tidak perlu dipelajari. Inilah salah satu faktor terbesar mundurnya keilmuan Islam. Bandingkan dengan abad pertengahan ketika muncul tokoh-tokoh yang tidak melihat dikotomi itu semisal Ya'qûb b. Ishâq alKindî (801-873 M) ${ }^{3}$, Abû Nâsir Muhammad. al-Farakh al-Fârâbî (257-339H/ 870950M) ${ }^{4}$ Abû Alî al-Husayn. Ibnu Sînâ (370-428H/980-1037M) $)^{5}$ yang di samping menguasai keilmuan Islam tradisional juga disegani sebagai pakar ilmu nonkeagamaan. Pada saat itu Islam mampu menunjukkan perannya sebagai kontributor ilmu ketika Barat sendiri mengalami kemunduran ilmiah. Tapi hari

\footnotetext{
${ }^{1}$ M. Amin Abdullah, "Visi Keindonesiaan Pembaharuan Pemikiran Islam Hermeneutik", Epistema, No. 02 (1999), h. 3.

${ }^{2}$ Muslim yang dimaksud adalah muslim yang masih memiliki paradigma berfikir pemisahan keilmuan, mereka meyakini bahwa keilmuan islam yang memiliki basis dalam alQur'an. Sehingga dari sisi keilmuan modern kaum muslimin yang memahami paradigma berfikir ini tertinggal dari negara-negara Barat.

${ }^{3}$ Seyyed Hossein Nasr, Intelektual Islam: Teologi, Filsafat dan Gnosis, terj. Suharsono dan Djamaluddin MZ (Yogyakarta: Pustaka Pelajar, 1996), h. 33-34.

${ }^{4}$ Munawir Sjadzali, Islam dan Tata Negara: Ajaran, Sejarah, dan Pemikiran (Jakarta: UIPress, 1991), h. 49.

${ }^{5}$ Fazlur Rahman, Islam, terj. Ahsin Mohammad (Bandung: Pustaka, 2000), h. 167. Lihat juga Nurcholish Madjid, Islam Doktrin dan Peradaban (Jakarta: Paramadina, 2000), h. 228.
} 
ini, akibat dikotomi yang telah diciptakan dan diwariskan sejak ratusan tahun itu, dunia Islam terpuruk dalam ketertinggalan. Barat ${ }^{6}$ sekarang tampil di puncak kemajuan peradaban ilmu.

Pendekatan integrasi-interkoneksi dalam pendidikan Islam mengandaikan terbukanya dialog di antara ilmu-ilmu. Peluang dikotomi ditutup rapat. Tiga peradaban dipertemukan di dalamnya, yakni hadârah al-nass (budaya teks), hadârah al-'ilm (budaya ilmu), dan hadârah al-falsafah (budaya filsafat). Pendekatan yang memadukan wahyu Tuhan dengan temuan pikiran manusia ini tidak akan berakibat mengecilkan peran Tuhan (sekularisasi) atau mengucilkan manusia sehingga teralienasi dari dirinya sendiri, masyarakat, dan lingkungannya. Namun konsep ini sekaligus akan dapat menyelesaikan konflik antara sekularisme ekstrem dan fundamentalisme negatif.

Gagasan Pemikiran M. Amin Abdullah tentang pendidikan Islam dengan menggunakan pendekatan integrasi-interkoneksi mencoba untuk memecahkan kebuntuan dari problematika kekinian. Sehingga dari berbagai disiplin keilmuan itu tidak hanya sampai pada sikap single entity (arogansi keilmuan: merasa satusatunya yang paling benar), isolated entities (dari berbagai disiplin keilmuan terjadi "isolasi", tiada saling tegur sapa), melainkan sampai pada interconnected entities (menyadari akan keterbatasan dari masing-masing disiplin keilmuan, sehingga terjadi saling kerjasama dan bersedia menggunakan metode-metode walaupun itu berasal dari rumpun ilmu yang lain). ${ }^{7}$

Dari hal ini penulis menelaah sejauh mana kajian pendidikan Islam dalam pemikiran M. Amin Abdullah. Sebab M. Amin Abdullah adalah seorang cendekiawan yang memiliki latar belakang keilmuan filsafat, tetapi dalam menapaki khazanah keilmuan Islam ia masuk pada wilayah pendidikan Islam.

Berangkat dari persoalan inilah penulis tertarik untuk mengkaji pemikiran M. Amin Abdullah tentang pendidikan Islam dalam pendekatan integrasiinterkoneksi. Penulis melihat telah terjadi analisis filsafat dalam membedah pendidikan Islam, dan sebagian besar kajian itu termuat dalam bukunya yang berjudul Islamic Studies di perguruan tinggi: pendekatan integratif-interkonektif.

\section{A. Dinamika Pendidikan Islam Di Indonesia \\ 1. Dikotomi Pendidikan Islam dan Umum}

Dalam kamus KBBI, istilah dikotomi memiliki arti pembagian atas dua konsep yang saling bertentangan. ${ }^{8}$ Dikotomi dalam bahasa Inggris adalah

\footnotetext{
${ }^{6}$ Yang dimaksud Barat yaitu merujuk kepada negara-negara yang berada di benua Eropa dan Amerika. Dunia Barat dibedakan dari dunia Timur yang digunakan untuk merujuk kepada Asia. Meskipun begitu, pada umumnya kata ini lebih sering diasosiasikan terhadap negara-negara yang mempunyai mayoritas penduduk berkulit putih. Oleh karena itu, Australia dan Selandia Baru juga sering dianggap sebagai bagian dari dunia Barat.

${ }^{7} \mathrm{M}$. Amin Abdullah, Islamic Studies di Perguruan Tinggi: Pendekatan IntegratifInterkonektif, (Yogyakarta: Pustaka Pelajar, 2006), h. 404-405. Lihat juga M. Amin Abdullah, "Desain Pengembangan Akademik IAIN Menuju UIN Sunan Kalijaga: Dari Pendekatan Dikotomis-Atomistis Kearah Integratif-Interkonektif” dalam Fahrudin Faiz, (ed.), Islamic Studies dalam Paradigma Integrasi-Interkoneksi (Yogyakarta: SUKA Press, 2007), h. 37-38.

${ }^{8}$ Departemen Pendidikan Kebudayaan Republik Indonesia. KBBI. (Jakarta: Balai Pustaka, 1991), h. 233.
} 
dichotomy yang artinya pembagian dua bagian, pembelahan dua, bercabang dua bagian. ${ }^{9}$ Ada juga yang mendefinisikan dikotomi sebagai pembagian di dua kelompok yang saling bertentangan. Secara terminologis, dikotomi dipahami sebagai pemisahan antara ilmu dan agama yang kemudian berkembang menjadi fenomena dikotomik-dikotomik lainnya, seperti dikotomi ulama dan intelektual, dikotomi dalam dunia pendidikan Islam dan bahkan dikotomi dalam diri muslim itu sendiri (split personality) Bagi al- Faruqi, dikotomi adalah dualisme religius dan kultural. ${ }^{10}$

Dengan pemaknaan dikotomi di atas, dikotomi pendidikan Islam adalah dualisme sistem pendidikan antara pendidikan agama Islam dan pendidikan umum yang memisahkan kesadaran keagamaan dan ilmu pengetahuan. Dualisme ini, bukan hanya pada dataran pemilahan tetapi masuk pada wilayah pemisahan, dalam operasionalnya pemisahan mata pelajaran umum dengan mata pelajaran agama, sekolah umum dan madrasah, yang pengelolaannya memiliki kebijakan masing-masing. Sistem pendidikan yang dikotomik pada pendidikan Islam akan menyebabkan pecahnya peradaban Islam dan akan menafikan peradaban Islam.

Pada hakikatnya tidak ada dikotomi dalam dunia pendidikan atau antara agama dan ilmu. Dikatakan adanya perbedaan agama dan ilmu pengetahuan pada dataran para ilmuan dan agamawan atau pada dataran manusia. Hal itu terjadi karena adanya pengaruh dari kekuasaan politik dan sistem hukum yang ada dan itu merupakan warisan sejarah yang berlangsung berabad-abad. ${ }^{11}$

Untuk memahami dikotomi pendidikan tampak jelas antara pendidikan Islam dan pendidikan umum. Jika pendidikan Islam lebih sering dipahami sebagai ilmu hadis, ilmu Qur'an, Aqidah Akhlak, sejarah Islam, ilmu Mantiq, filsafat Islam, ilmu qalam. Sementara ilmu umum yakni matematika, fisika, kimia, biologi, sosiologi, psikologi, antropologi, dan sebagainya.

Sebenarnya ilmu pendidikan Islam dan pendidikan umum non-dikotomik, karena secara esensial dan substansial terintegrasi dan terinterkoneksi, sehingga kedua keilmuan tersebut tidak dapat berdiri sendiri atau terpisah-pisah. Oleh karenanya justru Ilmu pengetahuan umum bermula dan berdasarkan dari agama. Jika ditelusuri historisitas pendidikan Islam dan pendidikan umum dapat diintegrasikan dan diinterkoneksikan sehingga tidak terdapat dikotomi pendidikan. $^{12}$

\section{Marginalisasi Pendidikan Islam}

Salah satu permasalahan Pendidikan Islam yang dihadapi bangsa Indonesia adalah rendahnya mutu pendidikan pada setiap jenjang dan satuan pendidikan. ${ }^{13}$ Banyak faktor yang ikut serta menentukan kualitas sumber daya

\footnotetext{
${ }^{9}$ Abdullah Hamid, dkk, Pemikiran Modern Dalam Islam, (Bandung: Pustaka Setia, 2010), h. 15 .

${ }^{10} \mathrm{http}$ ://jorjoran.wordpress.com/2011/04/04/dikotomi-dan-dualisme-pendidikan-diindonesia/.Diakses pada tanggal 30 Januari2016

${ }^{11}$ Maksudin, Pendidikan Karakter Non-Dikotomik, (Yogyakarta: Pustaka Pelajar, 2013), h. 97

${ }^{12}$ Ibid., h. 99.

${ }^{13}$ Departemen Agama, Rekonstruksi Sejarah Pendidikan Islam di Indonesia, h. 163.
} 
manusia (SDM), diantara strategi yang paling efektif dalam menentukan kualitas tersebut adalah melalui pendidikan. Maju mundurnya suatu masyarakat atau bangsa sangat ditentukan bagaimana pendidikan yang ditempuh masyarakat atau bangsa itu sendiri. Jadi maju mundurnya suatu masyarakat atau bangsa tergantung pada sebagian besar pendidikan yang berlaku dikalangan mereka.

Pendidikan Islam menjadi satu dalam sistem pendidikan nasional, tetapi predikat keterbelakangan dan kemunduran tetap melekat padanya, bahkan pendidikan Islam sering dinobatkan hanya untuk kepentingan orang-orang yang tidak mampu atau miskin, memproduk orang yang eksklusif, fanatik, dan bahkan pada tingkat yang sangat menyedihkan yaitu terorisme pun dianggap berasal dari lembaga pendidikan Islam, karena pada kenyataannya beberapa lembaga pendidikan Islam dianggap sebagai tempat berasalnya kelompok tersebut. Walaupun anggapan ini keliru dan dapat ditolak, sebab tidak ada lembagalembaga pendidikan Islam manapun yang bertujuan untuk memproduk atau mencetak kelompok-kelompok orang seperti itu. Tetapi realitas di masyakarat banyak perilaku kekerasan yang mengatasnamakan Islam.

Pendidikan Islam juga dihadapkan dan terperangkap pada persoalan yang sama, bahkan apabila diamati dan kemudian disimpulkan pendidikan Islam terkukung dalam kemunduran, keterbelakangan, ketidak berdayaan, dan kemiskinan, sebagaimana pula yang dialami oleh sebagian besar negara dan masyarakat Islam dibandingkan dengan mereka yang non Islam. Dapat dikatakan pendidikan Islam terjebak dalam lingkaran yang tak kunjung selesai yaitu persoalan tuntutan kualitas, relevansi dengan kebutuhan, perubahan zaman, dan bahkan pendidikan yang diberi embel-embel Islam, dianggap berkonotasi kemunduran dan keterbelakangan, meskipun sekarang secara berangsur-angsur banyak diantara lembaga pendidikan Islam yang telah menunjukkan kemajuan. Tetapi pendidikan Islam dipandang selalu berada pada posisi deretan kedua atau posisi marginal dalam sistem pendidikan nasional di Indonesia.

\section{Kualitas Pendidikan Islam}

Safi'i Maarif, menyatakan bahwa pendidikan Islam harus didesak untuk melakukan inovasi yang tidak hanya berkaitan dengan perangkat kurikulum dan manajemen, tetapi juga menyangkut dengan startegi dan taktik operasionalnya. Strategi dan taktik itu, menuntut perombakan model-model pendidikan sampai dengan institusi-institusinya, sehingga lebih efektif dan efisien, dalam arti pedagogis, sosiologis dan kultural dalam menunjukkan perannya. ${ }^{14}$ A. Syafii Maarif, menggambarkan situasi pendidikan Islam di Indonesia sampai awal abad ini tidak banyak berbeda dengan perhitungan kasar yang dikemukakan di atas. Sistem madrasah dan pesantren yang berkembang di nusantara ini dengan segala kelebihannya, juga tidak disiapkan untuk membangun peradaban. ${ }^{15}$

\footnotetext{
${ }^{14}$ A. Safii Maarif, Pendidikan Islam dan Proses Pemberdayaan Umat", Konsep dan Implementasi, Jurnal Pendidikan Islam, Th. I, Oktober 1992, Fakultas Tarbiyah UII Yogyakarta, h. 56 .

${ }^{15}$ Ibid., h. 57.
} 
Kegiatan pendidikan agama Islam yang berlangsung selama ini lebih banyak bersikap menyendiri, kurang berinteraksi dengan kegiatan-kegiatan pendidikan lainnya. Cara kerja semacam ini kurang efektif untuk keperluan penanaman suatu perangkat nilai yang kompleks. Pendidikan agama tidak boleh tidak boleh dan tidak dapat berjalan sendiri, tetapi harus berjalan bersama dan bekerjasama dengan program-program pendidikan nonagama kalau ingin mempunnyai relevansi terhadap perubahan sosial yang terjadi di masyarakat. ${ }^{16}$

\section{B. Basis Pendekatan Integrasi-Interkoneksi M. Amin Abdullah 1. Basis Historis-Filosofis}

Basis pendekatan Integrasi-Interkoneksi yang digagas oleh M. Amin Abdullah ini tidak lahir begitu saja, melainkan melalui proses perjuangan pemikiran yang panjang. Pada saat paradigma integrasi-interkoneksi ini digulirkan, muncul berbagai tanggapan, pandangan, komentar, masukan, juga kritikan. Namun disatu sisi M. Amin Abdullah memiliki ketegasan dalam membangun paradigma berfikir dalam rangka membangun pendidikan keislaman di Indonesia. Sebagai produk historis, tentu saja integrasi-interkoneksi memiliki konteks dan kapabilitasnya sendiri, sehingga kelemahan dan kekurangan ketika dilakukan implementasi pasti akan terjadi.

Dalam pandangan M. Amin Abdullah, problematika epistemologi dalam ilmu-ilmu keislaman dan pemikiran Islam pada umumnya semakin menjadi sasaran kritik secara akademik. M. Amin Abdullah memandang bahwa sarjana-sarjana Muslim seangkatan Fazlur Rahman yang mengambil posisi serupa yakni berangkat dari sebuah telaah kritis. ${ }^{17}$

Penulis mengamati basis historis-filosofis M. Amin Abdullah menawarkan konsep tentang pembagian keilmuan agama Islam ke dalam tiga wilayah, ${ }^{18}$ Pertama, wilayah praktik keyakinan dan pemahaman terhadap wahyu yang telah diinterpretasikan sedemikian rupa oleh para ulama, tokoh panutan masyarakat dan para ahli pada bidangnya dan oleh anggota masyarakat pada umumnya. Wilayah praktik ini umumnya tanpa melalui klarifikasi dan penjernihan teoretik keilmuan. Yang dipentingkan di sini adalah pengamalan. Pada level ini perbedaan antara agama dan tradisi, agama dan budaya, antara belief dan habits of mind sulit dipisahkan.

Kedua, wilayah teori-teori keilmuan yang dirancang dan disusun sistematika dan metodologinya oleh para ilmuan, para ahli, para ulama sesuai bidang kajiannya masing-masing. Apa yang disebut ulum al-tafsir, ulum alhadith, Islamic Thought (kalam, falsafah dan tasawuf), hukum dan pranata sosial (fikih), sejarah dan peradaban Islam, pemikiran Islam, dan dakwah Islam ada pada

\footnotetext{
${ }^{16}$ Ibid., h. 91.

${ }^{17}$ Lihat Musliadi, "Epistemologi Keilmuan Dalam Islam: Kajian Terhadap Pemikiran M. Amin Abdullah". Jurnal Pemikiran Islam UIN Aceh, Vol. No. 2. 2014. h. 44.

${ }^{18}$ Amin Abdullah, Filsafat Ilmu-ilmu Keislaman: Kajian Pendahuluan, dalam Seminar Nasional Pengujian Teori, STAIN Kudus, 12 Maret 2001. Lihat juga, Membangun Kembali Filsafat Ilmu-Ilmu Keislaman: Tajdid dalam Perspektif Filsafat Ilmu, dalam M. Amin Abdullah, Tajdid Muhammadiyah untuk Pencerahan Peradaban (Yogyakarta: MTPPI dan UAD Press, 2005), $27-45$
} 
wilayah ini. Apa yang ada pada wilayah ini sebenarnya tidak lain dan tidak bukan adalah teori-teori keilmuan agama Islam yang diabstraksikan baik secara deduktif dari nas-nas atau teks-teks wahyu maupun secara induktif dari praktek-praktek keagamaan yang hidup dalam masyarakat muslim era kenabian, sahabat, tabi'un maupun sepanjang sejarah perkembangan masyarakat Muslim di mana pun mereka berada.

Ketiga, adalah telaah kritis, yang lebih populer disebut meta discourse, terhadap sejarah perkembangan jatuh bangunnya teori yang disusun oleh kalangan ilmuan dan ulama pada lapis kedua. Lebih-lebih jika teori-teori pada disiplin tertentu, ulum al-Qur'an umpamanya didialogkan dengan teori-teori yang biasa berlaku pada wilayah lain, ulum al-hadith, sejarah peradaban Islam dan seterusnya. Teori yang berlaku pada wilayah kalam didialogkan dengan teori yang berlaku pada wilayah tasawuf, dan begitu selanjutnya. ${ }^{19}$

\section{Basis Normatif-Teologis}

Landasan normatif-teologis secara sederhana dapat diartikan sebagai suatu cara memahami sesuatu dengan menggunakan ajaran yang diyakini berasal dari Tuhan sebagaimana terdapat di dalam wahyu yang diturunkanNya. Kebenaran normatif teologis bersifat mutlak karena sumbernya berasal dari Allah Swt. Landasan ini akan memperkokoh bangunan keilmuan ilmu-ilmu umum (sainsteknologi dan sosial-humaniora). ${ }^{20}$

M. Amin Abdullah sendiri mengembangkan epistemologi integrasiinterkoneksi berlandaskan keilmuan al-Qur'an karena al-Qur'an tidak membedakan antara ilmu-ilmu agama (Islam) dan ilmu-ilmu umum (sainsteknologi dan sosial humaniora). Ilmu-ilmu agama (Islam) dan ilmu-ilmu umum (sains-teknologi dan social humaniora) tidak bisa dipisahkan satu sama lain. Bahkan Allah Swt berfirman di dalam surat al-Qashash ayat ke-77:

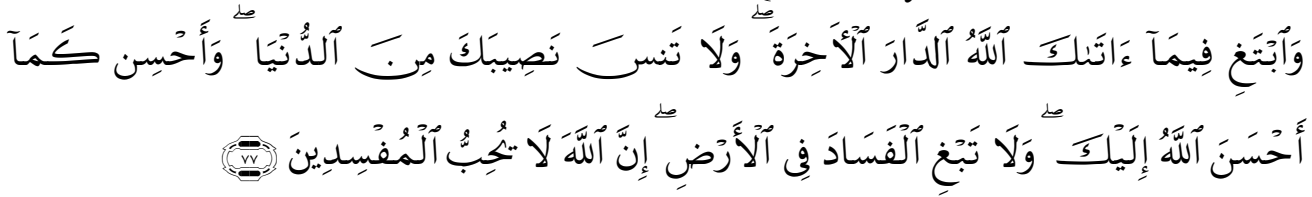

Terjemahnya:

Dan carilah pada apa yang telah dianugerahkan Allah kepadamu (kebahagiaan) negeri akhirat, dan janganlah kamu melupakan bahagianmu dari (kenikmatan) duniawi dan berbuat baiklah (kepada orang lain) sebagaimana Allah telah berbuat baik, kepadamu, dan janganlah kamu berbuat kerusakan di (muka) bumi. Sesungguhnya Allah tidak menyukai orang-orang yang berbuat kerusakan. ${ }^{21}$

\footnotetext{
${ }^{19}$ M. Amin Abdullah, Al-Takwin al-'Ilmiy: Ke Arah Perubahan Paradigma Penafsiran Kitab Suci, dalam M. Amin Abdullah, dkk. Tafsir Baru Studi Islam dalam Era Multi Kultural (Yogyakarta, Panitia Dies IAIN Sunan Kalijaga Yogyakarta ke-50, tahun 2001 dengan Kurnia Kalam Semesta, 2002), h. 78.

${ }^{20}$ Abuddin Nata Dkk, Prospek UIN Syarif Hidayatullah. (Jakarta: UIN Jakarta Press, 2006), h. 1.

${ }^{21}$ Kementerian Agama, Al-Qur'an dan Terjemahan
} 
Ayat tersebut menjelaskan bahwa tidak boleh memisahkan antara kepentingan kehidupan akherat (ilmu-ilmu agama) dan kepentingan kehidupan di dunia (ilmu-ilmu umum).

Al-Qur'an selain berisi ayat-ayat tentang ilmu ilmu agama juga berisi ayatayat tentang ilmu umum temasuk konsep-konsep dalam matematika, sebagai contoh Q.S. 35:1, 37:147,18:25, 29:14, dan lain-lain. Al-Qur'an juga memuat tentang metode pengembangan ilmu pengetahuan termasuk ilmu matematika, sebagai contoh Q.S. 2:31 (definisi) dan Q.S. 6: 74-79 (riset). Selanjutnya mengenai perintah untuk melakukan penelitian (suatu kegiatan yang penting di dalam pengembangan sains), secara umum dapat dilihat antara lain dalam firmanNya pada surat Yunus, ayat 101:

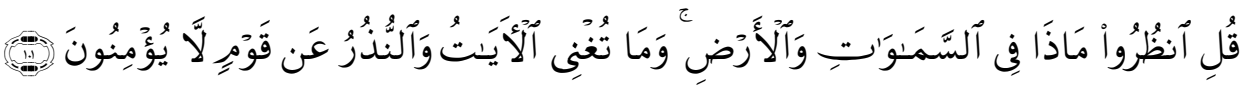

Terjemahnya:

Katakanlah Muhammad: lakukanlah nadzor (penelitian dengan menggunakan metode ilmiah) mengenai apa-apa yang ada di langit dan bumi.

Tidak diragukan lagi, satu hal yang disepakati bersama bahwa sumber ajaran Islam adalah al-Qur'an dan Sunnah, yang juga merupakan dasar bagi keilmuan Islam, karena keduanya diyakini mengandung kebenaran mutlak yang bersifat transendental dan universal. Inti ajaran Islam ini berlaku sama di manapun umat muslim berada dan kapanpun, mereka tidak akan pernah bisa lepas dari dua sumber tadi. Masalahnya kemudian adalah tingkat pemahaman, interpretasi, penghayatan, dan pelaksanaan norma-norma yang terkandung pada keduanya tidak sama antara satu tempat dengan tempat lainnya, antara satu zaman dengan zaman lainnya. Berbagai kondisi, suasana, budaya, bahasa dan faktor sosio-kultur lainnya mempengaruhi, dan dari perbedaan pemahaman ini sering melahirkan ketegangan-ketegangan antara umat Islam itu sendiri.

Di samping itu M. Amin Abdullah menyoroti pula problem keilmuan Islam klasik dalam mengurai berbagai persoalan empirik yang melekat dalam realitas kehidupan masyarakat modern seperti kemiskinan, lingkungan hidup, kebodohan, keterbelakangan, penindasan, dan lain-lain, yang dirasakan kurang mendapat porsi kepedulian yang menggigit dari pemikiran teologi para ulama dan para pemikir Islam. Dalam hal ini, M. Amin Abdullah melihat setidaknya ada tiga hal yang harus dibenahi terkait masalah sebagaimana di atas, yaitu metode tafsir al-Qur'an, metode pemaknaan hadis dan pengkajian pemikiran keislaman.

\section{Historisitas Pendekatan Integrasi-Interkoneksi}

Jika dilihat dari karya-karyanya, setidaknya ada dua pemikiran besar M. Amin Abdullah yang merespon persoalan yang sedang dihadapi oleh kaum Muslimin. Pertama adalah persoalan pemahaman terhadap keislaman yang selama ini dipahami sebagai dogma yang baku. Hal ini karena pada umumnya normativitas ajaran wahyu ditelaah lewat pendekatan doktrinal 
teologis. Pendekatan ini berangkat dari teks kitab suci yang pada akhirnya membuat corak pemahaman yang tekstualis dan skripturalis.

Sedangkan di sisi lain untuk melihat historisitas keberagamaan manusia, pendekatan sosial keagamaan digunakan melalui pendekatan historis, sosiologis, antropologis, dan lain sebagainya, yang bagi kelompok pertama dianggap reduksionis. Kedua pendekatan ini bagi M. Amin Abdullah merupakan hubungan yang seharusnya tidak dapat dipisahkan satu dengan lainnya. Kedua jenis pendekatan ini merupakan pendekatan yang bersifat teologisnormatif dan pendekatan yang bersifat historis-empiris sangat diperlukan dalam melihat keberagamaan masyarakat pluralistik. Kedua pendekatan ini akan saling mengoreksi, menegur, dan memperbaiki kekurangan yang. Karena pada dasarnya pendekatan apapun yang digunakan dalam studi agama tidak akan mampu menyelesaikan persoalan kemanusiaan secara sempurna. Pendekatan teologis-normatif saja akan menghantarkan masyarakat pada keterkungkungan berpikir sehingga akan muncul truth claim sehingga melalui pendekatan historis akan terlihat seberapa jauh aspek-aspek eksternal seperti aspek sosial, politik, dan ekonomi yang ikut bercampur dalam praktik-praktik ajaran teologis. ${ }^{22}$

Di sinilah, M. Amin Abdullah berusaha merumuskan kembali penafsiran ulang agar sesuai dengan tujuan dari jiwa agama itu sendiri, dan di sisi yang lain mampu menjawab tuntutan zaman, di mana yang dibutuhkan adalah kemerdekaan berpikir, kreativitas dan inovasi yang terus menerus dan menghindarkan keterkungkungan berpikir. Keterkungkungan berpikir itu salah satu sebabnya adalah paradigma deduktif, di mana meyakini kebenaran tunggal, tidak berubah, dan dijadikan pedoman mutlak manusia dalam menjalankan kehidupan dan untuk menilai realitas yang ada dengan hukum baku tersebut.

\section{Kontribusi Pemikiran M. Amin Abdullah Tentang Integrasi- Interkoneksi dalam Pendidikan}

M. Amin Abdullah mencurahkan gagasan tentang integrasi-interkoneksi dalam dunia pendidikan. Melalui lembaga UIN Sunan Kalijaga M. Amin Abdullah memperkenalkan keilmuan yang berbeda atau yang disebut sebagai pergeseran paradigma berfikir. Belakangan diketahui seiring pendekatan integrasiinterkoneksi yang digaungkan oleh UIN Sunan Kalijaga, Kementerian Pendidikan Nasional menerapkan Kurikulum 2013 dilembaga pendidikan, inti dari kurikulum tersebut adalah integrasi keilmuan.

Penulis sejauh ini mendalami kedua kurikulum baik integrasi-interkoneksi maupun kurikulum 2013. Secara epistemologi paradigma integrasi-interkoneksi yang digagas M. Amin Abdullah berbeda dengan kurikulum 2013. Hal ini tampak dengan jelas integrasi-interkoneksi lahir dari kegelisahan intelektual M. Amin Abdullah dalam menyoroti keilmuan Islam yang dikotomis. Sementara di sisi lain kurikulum 2013 lahir untuk menjawab tantangan pendidikan yang semakin hari

${ }^{22}$ M. Amin Abdullah, Studi Agama: Normativitas atau Historisitas?, (Yogyakarta: Pustaka Pelajar, 2002), h.18. 
semakin kompleks. Namun dari kedua paradigma ini memiliki misi yang tidak jauh berbeda alias memiliki sisi relevansi.

Untuk membedakan kurikulum 2013 kementerian Pendidikan Nasional yang menggunakan istilah tematik-integratif yang lebih menekankan sisi materi saja. Sementara M. Amin Abdullah menekankan pada muatan keilmuan yang dibekali dengan muatan spritualitas dan moral keagamaan yang lebih kritis dan terarah dalam format integrated curriculum, dan bukannya separated curriculum seperti yang berjalan selama ini. ${ }^{23}$

UIN Sunan Kalijaga tampil ditengah-tengah pergumulan keagamaan yang semakin kompleks yang bercita-cita melahirkan pendidikan Islam yang ideal di masa depan. Cita-cita ini berimplikasi dalam proses belajar mengajar secara akademik pada gilirannya akan menghilangkan dikotomi ilmu-ilmu umum dan ilmu-ilmu agama. ${ }^{24}$

Dalam ilmu kurikulum di UIN Sunan Kalijaga berbeda dengan beberapa istilah yang digunakan untuk menunjukan konsep "kurikulum terpadu" atau K13, yaitu: integrated, interdisciplinary, unit, fusi, broad field, dan sebagainya. Tentang perbedaan istilah-istilah yang digagas oleh Kementerian Pendidikan dan M. Amin Abdullah ini telah dijelaskan dalam sebuah tabel: ${ }^{25}$

\begin{tabular}{|l|l|}
\hline \multicolumn{1}{|c|}{ Istilah } & \multicolumn{1}{|c|}{ Makna } \\
\hline Integrated Curriculum & $\begin{array}{l}\text { Suatu model kurikulum yang dapat mengintegrasikan } \\
\text { antara skills, themes, concepts, dan topics secara inter } \\
\text { dan antar disiplin atau penggabungan keduanya. } \\
\text { Model kurikulum yang menawarkan sejumlah } \\
\text { kemungkinan tentang kesatuan dan keterkaitan antara } \\
\text { kegiatan-kegiatan sehari-hari dengan pengamalan } \\
\text { pendidikan. Kurikulum integrasi memiliki pola yang } \\
\text { lebih luas dan lebih terbuka. }\end{array}$ \\
\hline Interdisciplinary Curriculum & $\begin{array}{l}\text { Menunjuk pada suatu pola pemaduan antar dan inter } \\
\text { bidang studi, baik dua atau lebih bidang studi. }\end{array}$ \\
\hline Unite Curriculum & $\begin{array}{l}\text { Kurikulum unit menunjukkan adanya hubungan } \\
\text { antara aktivitas-aktivitas anak-anak-anak di sekolah, } \\
\text { pelajaran yang satu tidak lepas dari dari yang lain dan } \\
\text { merupakan satu kesatuan atau keseluruhan }\end{array}$ \\
\hline Broad Field Curriculum & $\begin{array}{l}\text { Satu jenis kurikulum yang menyatakan beberapa } \\
\text { mata pelajaran yang berdekatan atau berhubungan } \\
\text { menjadi satu bidang studi dengan menghilangkan } \\
\text { batas-batas masing-masing, misalnya sejarah, } \\
\text { geografi, dan ekonomi menjadi ilmu pengetahuan }\end{array}$ \\
\hline
\end{tabular}

\footnotetext{
${ }^{23}$ M. Amin Abdullah, Etika Tauhidik sebagai Dasar Kesatuan Epistemologi Keilmuan Umum dan Agama (dari Paradigma Positivistik-Sekularistik kearah Teoantroposentrisintegralistik), dalam Menyatukan Kembali Ilmu-ilmu Agama dan Umum: Upaya Mempertemukan Epistemologi Islam dan Umum, (Yogyakarta: Suka Press, 2003), h. 8.

${ }^{24}$ Waryani Fajar Riyanto, Integrasi-Interkoneksi Keilmuan, Biografi Intelektual M. Amin Abdullah (1953-...), (Yogyakarta: Suka Press, 2013), h. 1339.

${ }^{25}$ Ibid., h. 1340.
} 


\begin{tabular}{|l|l|}
\hline & sosial. \\
\hline Correlated Curriculum & $\begin{array}{l}\text { Ia merupakan subject curriculum, namun ada upaya } \\
\text { untuk menghubungkan dengan mata pelajaran atau } \\
\text { bidang studi lain dengan tetap mempertahankan } \\
\text { batas-batas yang ada. }\end{array}$ \\
\hline
\end{tabular}

Berdasarkan tabel di atas, terdapat perbedaan. Setidaknya ada tiga jenis atau tiga model materi dalam kurikulum 2013 yang menggunakan istilah: intradisipliner, multi-disipliner, dan trans-disipliner (memadukan antar disiplin ilmu yang satu rumpun, misalnya intra disiplin ilmu dalam natural sciences (Astronomi+fisika $=$ astrofisika) sosial sains (sosiologi-linguistik= sosiolinguistik), pengetahuan religius (tafsir+tarbiyah= Tafsir Tarbawi), dengan menggunakan metode masing-masing. Untuk antar-disipliner (memadukan antar disiplin ilmu yang berbeda rumpun, misalnya antara disiplin ilmu dalam natura sciences (biologi) dan social sciences (antropologi) menjadi antropobiologi. Dan interdisipliner (memadukan inter disiplin ilmu yang berbeda, misalnya antar disiplin ilmu dalam natural sciences (biologi) dan religious knowledge (etika), menjadi biotika, dengan menggunakan satu metode. Sementara M. Amin Abdullah menggunakan istilah trans-disipliner-hermeneutik. ${ }^{26}$

Titik relevansinya terletak pada wilayah pengintegrasian keilmuan. Sebab salah satu persoalan dalam dunia pendidikan dewasa ini adalah adanya dikotomi antara ilmu agama dengan ilmu umum. Pada era awal hingga abad pertengahan, sistem pendidikan yang dikembangkan oleh umat Islam sesungguhnya tidak mengenal adanya dikotomi antara ilmu agama Islam dengan ilmu umum. Pendidikan Islam yang dikembangkan justru mengemban misi untuk mengantarkan peserta didiknya agar dapat mencapai kebahagiaan dunia dan akhirat secara seimbang dan integral karena secara normatif-konseptual, dalam Islam tidak dijumpai adanya dikotomi tersebut. ${ }^{27}$

\section{E. Penilaian Atas Konsep Integrasi-Interkoneksi}

Yudian Wahyudi, guru besar UIN Sunan Kalijaga adalah cendekiawan yang sangat enerjik mengkritik konsep integrasi-interkoneksi M. Amin Abdullah. Ia menegaskan bahwa Pembelajaran integrasi interkoneksi akan terwujud dengan baik jika akar dari pembelajaran ini dapat di wujudkan dengan baik. Yudian Wahyudi mencontohkan pembelajaran terpadu yang telah di lakukan dalam pembelajaran yang dilakukan di sekolah yang sudah ia bangun yaitu sekolah

\footnotetext{
${ }^{26}$ Menurut M. Amin Abdullah, misalnya pendekatan multidisipliner, transdisiplin atau multi perspektif adalah ciri dari studi Islam kontemporer. Pendekatan transdisipliner inilah yang mencirikan pendekatan hermeneutik dalam studi keislaman. M. Amin Abdullah, "Metode Kontemporer dalam Tafsir al-Qur'an; Kesalingketerkaitan Asbab an-Nuzul al-Qadim dan al-Jadid dalam Tafsir al-Qur'an Kontemporer". Makalah ini disampaikan dalam Seminar Nasional In Search for Contemporary Methods of the Qur'anic Interpretation, diselenggarakan oleh CSS MORA UIN Sunan Kalijaga kerjasama dengan BMJ Tafsir Hadis, Fakultas Ushuluddin, Studi Agama dan Pemikiran Islam UIN Sunan Kalijaga, 25 Februari 2012, h. 3-4.

${ }^{27}$ Abd. Rachman Assegaf, Kata Pengantar, dalam Jasa Ungguh Muliawan, Pendidikan Islam Integratif, Upaya Mengintegrasikan Kembali Dikotomi Ilmu dan Pendidikan Islam, (Yogyakarta: Pustaka Pelajar, 2005), h. viii-ix.
} 
Sunan Averous. Pembelajaran yang dilakukan disana yaitu dengan mengintegrasikan berbagai mata pelajaran dengan agama. Misalnya dalam belajar bahasa Inggris, maka bacaan yang diberikan yaitu tentang agama, sedangkan saat mencontohkan maka dicontohkan dengan berbagai macam kegiatan keagamaan seperti salat dan lain sebagainya. Begitu juga saat belajar Matematika, pembelajaran yang dilakukan juga harus menyisipkan satu kata bahasa Arab yang dapat dikaitkan dengan materi Matematika. Yudian Wahyudi juga menegaskan bahwa butuh waktu 50 tahun untuk mewujudkan integrasi-interkoneksi yang sudah dirintis oleh M. Amin Abdullah. ${ }^{28}$

M. Amin Abdullah menyadari perlu ada penyatuan dan dialog dalam satuan keilmuan pendidikan Islam. Pandangannya tentang integrasi-interkoneksi berpijak pada satu tujuan yakni melahirkan keilmuan yang mumpuni dalam menuju peradaban Islam. Yang dimaksud dengan keilmuan yang mumpuni adalah ilmu yang bukan sekadar bicara tentang tauhid, akan tetapi juga berbicara tentang kemodernan. Dengan kata lain, cita-cita pendidikan Islam itu sejalan dengan citacita peradaban Islam. Sebab Islam dalam pengertiannya sebagai agama rahmat bagi seluruh alam.

Sebagaimana telah dijelaskan sebelumnya, bahwa basis integrasiinterkoneksi yakni, historis-filosofis dan teologis-normatif, artinya dalam pendidikan Islam, basis ini dapat mengungkap berbagai persoalan lewat pendekatan multidisipliner keilmuan. Namun epistemologi keilmuan tersebut dalam sejarahnya hanya sekadar dipergunakan dalam peralihan status IAIN ke UIN, dalam hal ini adalah UIN Sunan Kalijaga. Tetapi komitmen tentang integrasi-interkoneksi itu kurang bergaung dalam hal keilmuan. Kemudian yang perlu dikritisi dalam pendekatan integrasi-interkoneksi ini yakni keilmuan yang masih berputar pada perguruan tinggi tanpa menyentuh pada masyarakat luas. Artinya, pendekatan integrasi-interkoneksi dalam pendidikan Islam hanya sebagai konsumsi para akademisi, sehingga yang terjadi pada pendekatan tersebut kurang tersosialisasi pada masyarakat luas.

\section{Penutup}

Dinamika pendidikan Islam diIndonesia menunjukan dikotomi pendidikan, baik pendidikan Islam maupun pendidikan Umum. Umat Islam selama ini memahami bahwa pendidikan Islam dan Umum telah tampak dalam pelajaran umum dan juga pelajaran agama. Pendidikan Islam sering dinobatkan hanya untuk kepentingan orang-orang yang tidak mampu atau miskin, memproduk orang yang eksklusif, fanatik, dan bahkan pada tingkat yang sangat menyedihkan yaitu terorisme pun dianggap berasal dari lembaga pendidikan Islama. Inilah yang disebut sebagai marginalisasi pendidikan Islam. Selain itu kualitas pendidikan Islam disebut sangat terbelakang atau kurang berkualitas. Pandangan M. Amin Abdullah tentang pendidikan Islam dalam pendekatan integrasi-interkoneksi mengurai tentang basis pendekatan integrasi-interkoneksi M. Amin Abdullah dalam konsep pendidikan Islam. Memiliki akar yang sangat jelas dalam dunia

\footnotetext{
${ }^{28}$ https://anafitrotunnisa.wordpress.com/2015/11/29/national-seminar-report-ofrekonstruksi-kurikulum-sekolah-berbasis-integrasi-interkoneksi/. Diakses tanggal 26 Februari 2016.
} 
ilmu pengetahuan kedudukan pendidikan Islam mencakup hadlarah al-nash, hadlarah al-ilm, dan hadlarah al-falsafah adalah upaya mempertemukan kembali antara ilmu-ilmu keislaman (islamic science) dengan ilmu-ilmu umum (modern science). Pentingngnya ilmu pengetahuan yang menyatu atau bertegur sapa dalam ruang lingkup dialog keilmuan. Kurikulum integrasi-interkoneksi di UIN Sunan Kalijaga mencerminkan kurikulum paralel, linier dan sirkular Sehingga paradigma integrasi-interkoneksi M. Amin Abdullah dalam implementasinya melahirkan kurikulum bercorak integrasi-interkoneksi keilmuan. 


\section{DAFTAR PUSTAKA}

Abdullah, M. Amin, "Visi Keindonesiaan Pembaharuan Pemikiran Islam Hermeneutik", Epistema, No. 02 (1999)

, Filsafat Ilmu-ilmu Keislaman: Kajian Pendahuluan, dalam Seminar Nasional Pengujian Teori, STAIN Kudus, 12 Maret 2001.

, Membangun Kembali Filsafat Ilmu-Ilmu Keislaman: Tajdid dalam Perspektif Filsafat Ilmu, dalam M. Amin Abdullah, Tajdid Muhammadiyah untuk Pencerahan Peradaban (Yogyakarta: MTPPI dan UAD Press, 2005)

, Al-Takwin al-'Ilmiy: Ke Arah Perubahan Paradigma Penafsiran Kitab Suci, dalam M. Amin Abdullah, dkk. Tafsir Baru Studi Islam dalam Era Multi Kultural (Yogyakarta, Panitia Dies IAIN Sunan Kalijaga Yogyakarta ke-50, tahun 2001 dengan Kurnia Kalam Semesta, 2002)

, Islamic Studies di Perguruan Tinggi: Pendekatan Integratif-Interkonektif, (Yogyakarta: Pustaka Pelajar, 2006)

, "Desain Pengembangan Akademik IAIN Menuju UIN Sunan Kalijaga: Dari Pendekatan Dikotomis-Atomistis Kearah Integratif-Interkonektif' dalam Fahrudin Faiz, (ed.), Islamic Studies dalam Paradigma IntegrasiInterkoneksi (Yogyakarta: SUKA Press, 2007)

, Studi Agama: Normativitas atau Historisitas?, (Yogyakarta: Pustaka Pelajar, 2002)

, Etika Tauhidik sebagai Dasar Kesatuan Epistemologi Keilmuan Umum dan Agama (dari Paradigma Positivistik-Sekularistik kearah Teoantroposentrisintegralistik), dalam Menyatukan Kembali Ilmu-ilmu Agama dan Umum: Upaya Mempertemukan Epistemologi Islam dan Umum, (Yogyakarta: Suka Press, 2003)

, "Metode Kontemporer dalam Tafsir al-Qur'an; Kesalingketerkaitan Asbab an-Nuzul al-Qadim dan al-Jadid dalam Tafsir al-Qur'an Kontemporer". Makalah Februari 2012

Assegaf, Abd. Rachman Assegaf, Kata Pengantar, dalam Jasa Ungguh Muliawan, Pendidikan Islam Integratif, Upaya Mengintegrasikan Kembali Dikotomi Ilmu dan Pendidikan Islam, (Yogyakarta: Pustaka Pelajar, 2005)

Departemen Agama, Rekonstruksi Sejarah Pendidikan Islam di Indonesia

Departemen Pendidikan Kebudayaan Republik Indonesia. KBBI. (Jakarta: Balai Pustaka, 1991) 
Hamid Abdullah, dkk, Pemikiran Modern Dalam Islam, (Bandung: Pustaka Setia, 2010)

Nasr, Seyyed Hossein, Intelektual Islam: Teologi, Filsafat dan Gnosis, terj. Suharsono dan Djamaluddin MZ (Yogyakarta: Pustaka Pelajar, 1996)

Maksudin, Pendidikan Karakter Non-Dikotomik, (Yogyakarta: Pustaka Pelajar, 2013)

Maarif, A. Safii, Pendidikan Islam dan Proses Pemberdayaan Umat", Konsep dan Implementasi, Jurnal Pendidikan Islam, Th. I, Oktober 1992, Fakultas Tarbiyah UII Yogyakarta

Musliadi, "Epistemologi Keilmuan Dalam Islam: Kajian Terhadap Pemikiran M. Amin Abdullah”. Jurnal Pemikiran Islam UIN Aceh, Vol. No. 2. 2014.

Rahman, Fazlur, Islam, terj. Ahsin Mohammad (Bandung: Pustaka, 2000), h. 167. Lihat juga Nurcholish Madjid, Islam Doktrin dan Peradaban (Jakarta: Paramadina, 2000)

Nata, Abuddin, Dkk, Prospek UIN Syarif Hidayatullah. (Jakarta: UIN Jakarta Press, 2006)

Riyanto, Waryani Fajar, Integrasi-Interkoneksi Keilmuan, Biografi Intelektual M. Amin Abdullah (1953-...), (Yogyakarta: Suka Press, 2013)

Sjadzali, Munawir, Islam dan Tata Negara: Ajaran, Sejarah, dan Pemikiran (Jakarta: UI-Press, 1991)

https://anafitrotunnisa.wordpress.com/2015/11/29/national-seminar-report-ofrekonstruksi-kurikulum-sekolah-berbasis-integrasi-interkoneksi/. Diakses tanggal 26 Februari 2016.

http://jorjoran.wordpress.com/2011/04/04/dikotomi-dan-dualisme-pendidikan-diindonesia/ Diakses pada tanggal 30 Januari 2016 